\title{
A Correlative Study to Assess the Knowledge and Practice of Housewives Regarding Householdwaste Management in Selected Rural Community at Mangalore with a View to Provide an Information Pamphlet
}

\author{
Abin Baby ${ }^{1}$, Shycil Mathew ${ }^{2}$ \\ ${ }^{I}$ Nursing, Lecturer Dept. of Community Health Nursing, City College of Nursing, ${ }^{2}$ Lecturer Department of \\ Community Health Nursing, Yenepoya Nursing College, Yenepoya (Deemed to be University), \\ Deralakatte, Mangaluru, Karnataka, India
}

\begin{abstract}
Background: Improper waste management deteriorates public health, degrades quality of life, and pollutes local air, water and land resources. It also causes global warming and climate change and impacts the entire planet. Environmental problem faced by communities living near garbage dumps and marshy lands include air pollution, fires, smoke, flooding etc. Long term health problems like asthma, bronchitis, hepatitis, jaundice, malaria, elephantiasis and typhoid too have been faced by communities. So waste which are considered to be hazardous need to be disposed off safely and adequately.

Materials and Method: A descriptive correlative research design was used for this study. The sample comprised of 60 housewives between 18-55 years of age. The sample was drawn through purposive sampling technique. The study was carried out in rural community at Mangalore. A structured knowledge questionnaire was used to determine the knowledge of the subjects and practice rating scale was administered to assess the practice scores of housewives regarding household waste management.

Results: Majority of the subjects (65\%) were having only average knowledge with knowledge score ranging between 0-20 with median 18 and SD 3.01 and majority of the subjects were have moderate practice score on waste management with median 20 and SD 3.52. There was a significant relationship between knowledge score and practice score of the subjects on waste management $(\mathrm{r}=0.346, \mathrm{df}=59.000, \mathrm{p}<0.05)$. Conclusion: The findings of this study suggest that there is a need for educating the mothers regarding the proper household waste management. Women take a key role in housekeeping and disposing domestic waste. So the Government and frontline health workers need to take special initiatives to curb this public issue.
\end{abstract}

Keywords: Knowledge; practice; waste management; housewives; information pamphlet.

\section{Introduction}

\section{Correspondence Address:}

\section{Ms. Shycil Mathew}

M.Sc. Nursing, Department of Community Health

Nursing, Yenepoya Nursing College, Yenepoya

(Deemed to be University), Deralakatte, Mangaluru,

Karnataka-575018

e-mail: shycilplakkattu7070@gmail.com

Contact No.: 9538812499
Waste is a material that no longer serves a purpose and so is thrown away ${ }^{(1)}$. In somecases what one person discards may be re-used by someone else ${ }^{(2)}$. All wastes are particularly hazardous ${ }^{(3)}$. Improper disposal of wastes causes negative impact on the environment, whether it is unsightly litter in urban streets or contaminated air, soil or water ${ }^{(4)}$.This improper waste disposal can affect the life negatively by creating an 
environment that is potent for developing diseases in man as well as other living things. Toxic waste can seep into the ground and contaminate our water supplies, and sometimes cause widespread diseases. Due to uncollected waste and improper disposal techniques drains also get clogged which lead to mosquitoes by which various diseases like malaria, chikungunya, viral fever, dengue etc. arise and affect the health of people adversely ${ }^{(4,5)}$.The output of daily waste depends upon the dietary habits, lifestyles, living standards, and the degree of urbanization and industrialization ${ }^{(6)}$. In India we produce 300 to $400 \mathrm{Gms}$ of solid waste per person per day in town of Normal size but exceptionally about 500 to $800 \mathrm{gms}$ of solid waste is generated per capita per day in metro cities like Delhi and Bombay ${ }^{(7)}$. The total population of Karnataka as per 2011 census is 5.273 core (52.73), Urban 33.98\% and rural 66.01\%. In Karnataka the waste quantities are estimated to increase from 46 million tons in 2001 to 65 million tons in $2015^{(7,6)}$. In a day-to-day life many people are unaware of the proper domestic waste disposal and its harmful effects on the health and environment ${ }^{(8)}$. Community based education, especially in women, on household waste management and hygiene is essential in order to improve the health of the community ${ }^{(9)}$.

Aim: The aim of this study is to assess the knowledge and practice of housewives regarding household waste management in a selected rural community at Mangalore with the view to provide an information pamphlet.

\section{Objectives of the Study:}

1. To determine the level of knowledge regarding household waste management among housewives as measured by a structured knowledge questionnaire.

2. To identify the practice of housewives on household waste management as measured by a practice rating scale.

3. To find the relationship of knowledge and practice scores of housewives on household waste management.

4. To find the association of knowledge scores of housewife on household waste management with the selected demographic variables.

5. To find the association of practice scores of housewife on household waste management with the selected demographic variables.

\section{Materials and Method}

Study setting and sample size: A descriptive correlative research design was used for this study. The sample comprised of 60 housewives between 18-55 years of age. The samples were selected by purposive sampling technique. The study was carried out in rural community at Mangalore, India. Astructured knowledge questionnaire was used to determine the knowledge of the subjects with 34 knowledge items with the maximum score of 34 to assess the knowledge of housewives regarding household waste management. and practice rating scale was administered to assess the practice scores of housewives regarding household waste management with 17 statements with three point scale i.e. always, sometimes and never. The statements were scored 2, 1, 0 respectively. The maximum possible score is 34 . In order to educate the housewives on this regard the investigator has developed and distributed an information pamphlet to all subjects after collecting the data.

Data Analysis: The data was collected after obtaining prior permission from the concerned authority to conduct the study. The participants were assured about the confidentiality of their responses. The data was analyzed in terms of objectives of the study using both descriptive and inferential statistics. The data obtained was plotted in the master sheet.

\section{Findings:}

\section{Results}

\section{Section I. Description of baseline Proforma}

- Maximum number of subjects (38.3\%) were in the age group of 30-39 yrs.

- Maximum number of subjects (48.3\%) were Muslims

- Most of the subjects (40\%) have primary education

- Most of the subjects (45\%) belong to nuclear family

- Majority of the subjects (40\%) had monthly income of 4001-6000

- Most of the subjects (41.7\%) received information from Magazines/Newspapers. 
Section II: Knowledge score obtained by the subjects regarding household waste management.

- Majority of the subjects (65\%) have average knowledge, $33.3 \%$ of subjects have good knowledge and only $1.7 \%$ of them have excellent knowledge regarding house hold waste management. This shows that majority of the subjects $(65 \%)$ have only average knowledge regarding house hold waste management. (figure-1)

Section III: Practice score of subjects regarding household waste management

- Out of 60 housewives, $80 \%$ housewives had average disposal practices, $20 \%$ had good practices on disposal of house hold waste management. (Table-1).

Section IV: Correlation relationship between knowledge and practice scores of subjects regarding household waste management

- There is a moderate positive correlation between the knowledge and practice score $(\mathrm{r}=-0.346, \mathrm{df}=58$, table value $=0.236)$. (Table-2)

Section V: Association between knowledge score and selected demographic variables.

- There is no significant association between knowledge score with demographic variables except in religion and educational qualification.

Section VI: Association between practice score and selected demographic variables

- There is no association between practice score of subjects with demographic variables

\section{Discussion}

- The present study revealed that, majority of the subjects $(65 \%)$ have average knowledge, $33.3 \%$ of subjects have good knowledge and only $1.7 \%$ of them have excellent knowledge regarding house hold waste management.

- Results obtained from this study consistent to the results reported in another study conducted by Arora $\mathrm{L}$ et al it was found that $162(54 \%)$ of the respondents could be classified as possessing low knowledge, whilst 138(46\%) respondents were having medium level of knowledge regarding waste management ${ }^{(2)}$.

- In present study results revealed that out of 60 housewives, $80 \%$ housewives had average disposal practices, $20 \%$ had good practices on proper disposal of house hold waste management .

The findings of the study was similar the study conducted by John Jince V el al(2014) 75.1\% had average practice, $24.9 \%$ had ppor practice and none of them had good practice regarding domestc waste management ${ }^{(13)}$.

There is moderate positive correlation between the knowledge and practice score $(\mathrm{r}=-0.346, \mathrm{df}=58$, table value $=0.236$ ).

The findings of the study was similar the study conducted by John Jince V el al(2014) The study shows a positive correlation between knowledge and practice of housewives on management of domestic plastic waste $(\mathrm{r}=0.071)^{(13)}$

Section II: Knowledge score obtained by the subjects regarding household waste management.

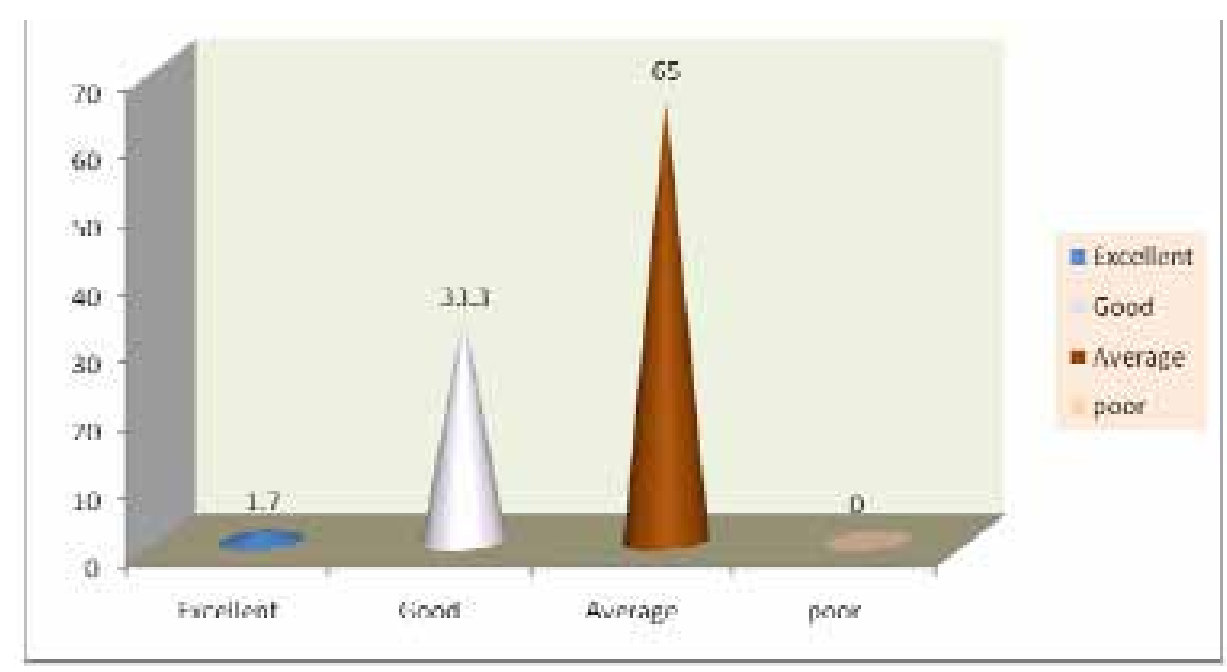

Figure 1: Cone diagram showing the distribution of subjects according to the grades of knowledge score. 
Section III: Practice score of subjects regarding household waste management.

Table 1: Distribution of practice score of subjects on household waste management in terms of frequency and percentage $\mathrm{N}-60$

\begin{tabular}{|c|c|c|c|}
\hline Practice Score & Grade & Frequency & Percentage \\
\hline $23-34$ & Good & 12 & 20 \\
\hline $12-20$ & Average & 48 & 80 \\
\hline $0-11$ & Poor & 0 & 0 \\
\hline
\end{tabular}

Section IV: Table 2: Correlation between knowledge and practice of subjects on household waste management. N-60

\begin{tabular}{|l|c|c|c|c|c|c|}
\hline Variables & Max Score & Min Score & SD & r value & df & Inference \\
\hline Knowledge & 31 & 16 & 3.01 & \multirow{2}{*}{0.346} & \multirow{2}{*}{58} & Significant \\
\cline { 1 - 5 } Practice & 30 & 15 & 3.52 & & & \\
\hline
\end{tabular}

' $\mathrm{r}$ '=0.346 at $\mathrm{df}=58$

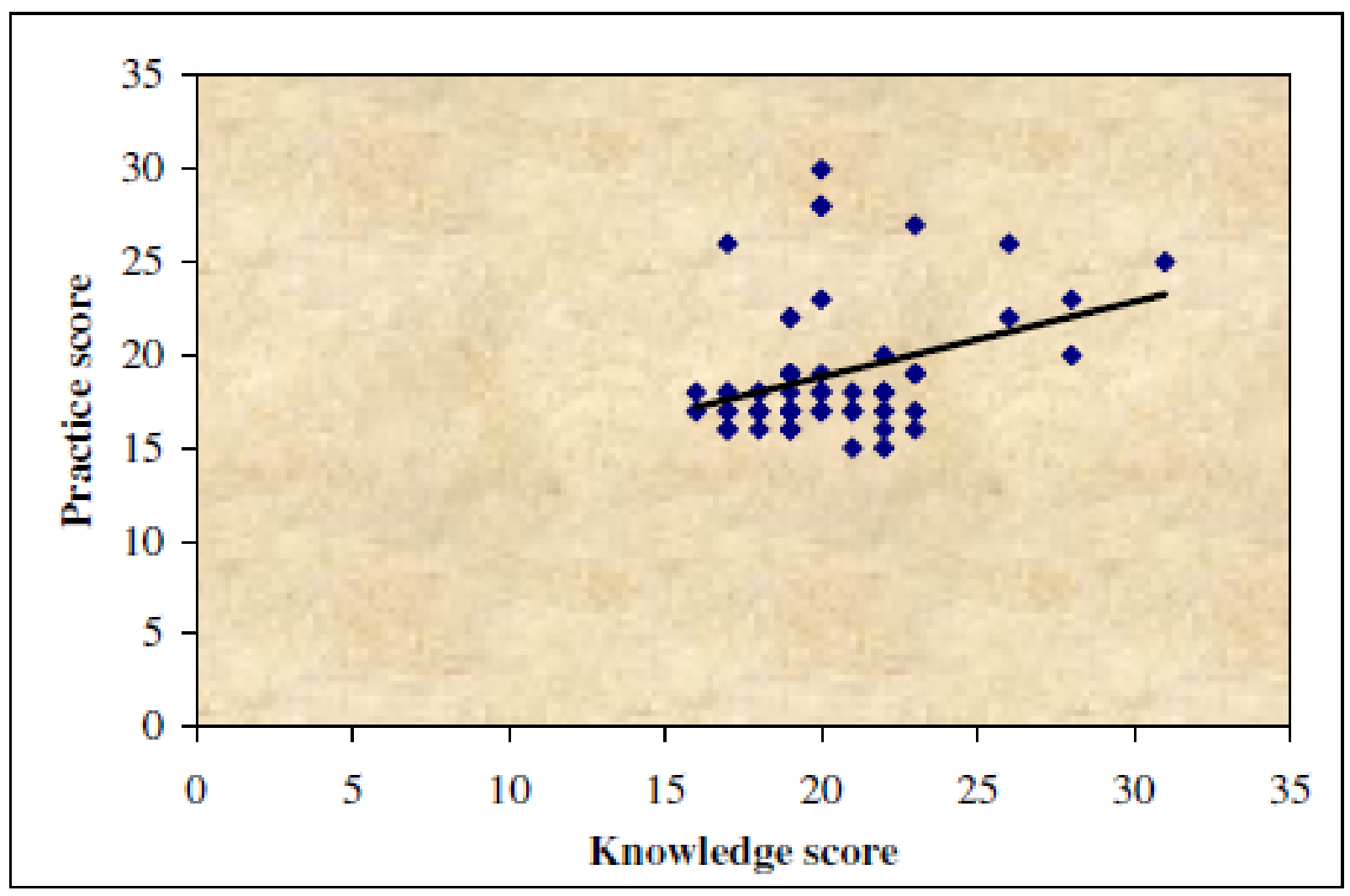

Figure 2: Scatter diagram showing the correlation between knowledge and practice scores of housewives

regarding household waste management

\section{Conclusion}

The findings of this study revealed that, majority of the subjects had only average knowledge regarding household waste management and the study suggest that there is a need for educating the mothers regarding the proper waste disposal,since the women take a key role in housekeeping and disposing domestics waste. So the Government and frontline health workers need to take special initiatives to curb this public issue. 
Acknowledgement: The investigator sincerely acknowledges the support given by Mrs. Shycil Mathew, Shanti Lobo and Janat Miranda for their timely support and smart guidance to complete the project. Sincere gratitude towards the study participants for their cooperation.

\section{Financial support and sponsorship: Nil}

Conflicts of Interest: There are no conflicts of interest

Ethical Clearance: Written informed consent was obtained from the housewives .Ethical clearance was obtained from institutional ethics committee of CHCT, Mangalore.

\section{Reference}

1. Desa A, Kadir NB, Yusooff F. Environmental Awareness and Education: A Key Approach to Solid Waste Management (SWM)-A Case Study of a University in Malaysia. Waste ManagementAn Integrated Vision. 2012 Oct 26.

2. Kiran KG, Kini S, Ravi K, Santhosh NP, Kiran NU. KAP study of solid waste disposal of households in Kuttar \& Manjanadi Panchayath covered under gramaskhema programme of KS Hegde Medical Academy. Nitte University Journal of Health Science. 2015 Sep 1;5(3):29.

3. Bartelings $\mathrm{H}$, Sterner T. Household waste management in a Swedish municipality: determinants of waste disposal, recycling and composting. Environmental and resource economics. 1999 Jun 1;13(4):473-91.

4. Afroz R, Hanaki K, Tudin R. Factors affecting waste generation: a study in a waste management program in Dhaka City, Bangladesh. Environmental monitoring and assessment. 2011 Aug 1;179(14):509-19.

5. Afroz R, Hanaki K, Hasegawa-Kurisu K. Willingness to pay for waste management improvement in Dhaka city, Bangladesh. Journal of environmental management. 2009 Jan 1;90(1):492-
503.

6. De Feo G, De Gisi S. Public opinion and awareness towards MSW and separate collection programmes: A sociological procedure for selecting areas and citizens with a low level of knowledge. Waste Management. 2010 Jun 1;30(6):958-76.

7. Rajendra Kumar Kaushal et al./International Journal of Engineering Science and Technology (IJEST).Municipal Solid Waste Management in India-Current State and Future Challenges: A Review; 2008. p.112-19

8. Ehrampoush MH, Moghadam MB. Survey of knowledge, attitude and practice of Yazd University of Medical Sciences students about solid wastes disposal and recycling. Journal of Environmental Health Science \& Engineering. 2005;2(2):26-30.

9. Desa A, Kadir NB, Yusooff F. A study on the knowledge, attitudes, awareness status and behaviour concerning solid waste management. Procedia-Social and Behavioral Sciences. 2011 Jan 1;18:643-8.

10. Ahmad J, Noor SM, Ismail N. Investigating Students' Environmental Knowledge, Attitude, Practice and Communication. Asian Social Science. 2015 Jul 1;11(16):284.

11. Jalil MA. Sustainable development in Malaysia: A case study on household waste management. Journal of Sustainable Development. 2010 Sep 1;3(3):91.

12. Karout N, Altuwaijri S. Impact of health education on community knowledge, attitudes and behaviour towards solid waste management in Al Ghobeiry, Beirut. EMHJ-Eastern Mediterranean Health Journal, 18 (7), 777-785, 2012. 2012.

13. John JV, Fernandes ST, Kuriakose S. Knowledge and Practice of Housewives on Domestic Plastic Waste Management. International Journal of Nursing Education. 2014;6(1):155-60.

14. Gracy R. A study to assess the knowledge and practice regarding the proper disposal of refuse and sewage among housewives in a selected rural area of hesaraghatta, Bangalore with a view to develop a booklet (Doctoral dissertation). 